\title{
Implications of density bonus tool for urban planning: relaxing floor area ratio (FAR) regulations in Tehran
}

\section{Katayoun Karampour}

Bartlett School of Planning, The Bartlett, University College London, UK

Correspondence details:

Bartlett School of Planning

Fifth Floor

Central House

14 Upper Woburn Place

London, WC1H 0NN

UK

Tel: +44 (0)2031089947

Email: k.karampour@ucl.ac.uk

Biography:

I am a Teaching Fellow in Urban Design and Planning at Bartlett School of Planning. I studied in Tehran for a BSc in Built Environment Conservation and an MA in Architecture (Revitalisation of Historic Neighbourhoods), and then was awarded an MSc in Urban Regeneration (2010) and a PhD in Planning Studies (2018) by UCL's Bartlett School of Planning. 


\section{Implications of density bonus tool for urban planning: relaxing floor area ratio (FAR) regulations in Tehran}

This article, by using empirical evidence from Tehran, looks beyond the West to explore the implications of the reliance of the entrepreneurial local government on private capital for the urban planning system. The main premise of this paper is that the financial dependence of Tehran Municipality on income generated from increasing construction density (density bonus tool) paid by developers has led to a planning that is responsive to property market interests rather than the city's strategic needs or the public interest. This paper makes a contribution to the literature of urban planning by providing a new case study of density bonus tool focused in Tehran; that allows a better understanding the issue of how municipal financial tools (such as density bonus) could affect planning decisions.

Keywords: entrepreneurial governance; symbiotic planning; marketisation of planning; density bonus; Tehran; urban planning

\section{Introduction}

Since the late 1970s and the 1980s, for ideological and economic reasons, many states around the world have turned towards neoliberal policies (Harvey, 2005). Neoliberalism, which is about deregulation, liberalisation and state retrenchment (Brenner and Theodore, 2008), has pushed local governments towards 'entrepreneurial governance' and the decentralisation of central government (Harvey, 1989). As a result, local governments have been put under pressure to find ways to fund their expenditures through private capital. Alternative ways that local governments have employed recently to finance their costs or deliver local services have included: impact fees; transferable development rights and development charges in some states of the USA and Canada; selling additional construction bonds in Brazil; valorisation taxes in Colombia; and developer contributions (planning gains) in Britain. In other words, in order to implement public planning policies, municipalities are increasingly relying on 
the financial resources of property developers and investors (Heurkens and Hobma, 2014).

There have been a number of studies devoted to the analysis of the different techniques that have been used to charge developers in different contexts so that the expenses of municipalities can be funded (e.g. Bird and Slack, 2007; Slack, 2009; Ingram and Hong, 2010). There have also been studies carried out on the impact of these charges on the property market (e.g. Singell and Lillydahl, 1990; Skaburskis and Qadeer, 1992; Ihlanfeldt and Shaughnessy, 2004). However, there have been few empirical studies conducted across the world (e.g. Slack, 2002; Jou et al., 2012; Burgess and Monk, 2016) on the implications that these municipal revenue-raising regimes have on planning objectives and their potential impact on the future development of the city.

To address the deficiency of empirical studies on the implications of the reliance of local governments on private capital for urban planning objectives (Tasan-Kok and Baeten, 2012) and also to follow the post-colonial approach of urban study (Robinson, 2002, 2003, 2006; Roy, 2009; Goodfellow, 2018) this paper uses empirical evidence from Tehran to explore this situation. It has been more than three decades since the Tehran Municipality received any money from central government and it is financially independent. Hence, studying the case of Tehran could shed some light for other authorities on the consequences of relying on private capital to provide public services.

The reasons for the selection of Tehran as a case study are explained in detail in the methodology section of this paper, but can be summarised as follows. For more than three decades, Tehran Municipality has relied on development charges and other nongovernmental funds to manage the city. This was the result of the combination of several events. After the Islamic revolution in 1979, despite the initial aim of Iran's government being to address 'the decadence of unbridled market individualism' 
(Harvey, 2005, p. 85), it had not abandoned its market-based practices. In the aftermath of the Iran-Iraq war (took place between 1980 and 1988), Iran was under economic pressure which resulted in a restructuring of the economy. Rafsanjani, president at the time, 'pushed for changes to labour, banking, and property laws to attract foreign investment'. He and his allies argued that 'deregulation, privatisation, and cuts in subsidies and public services' were necessary to achieve economic growth (Pourzal, 2008, p. 20). Moreover, international sanctions against Iran in recent decades pushed the country to continue to adopt austerity measures to address economic pressures.

Tehran has pursued the government's agenda since the late 1980s, aiming to become financially independent from central government. Since then, the municipality has started to make use of various entrepreneurial tools to assist in providing funding the city, such as granting excess construction density to developers (increase in Floor Area Ratio- density bonus), which has enabled them to construct taller buildings in exchange for a fee. This funding tool has generated a significant amount of money for the municipality and boosted the housing construction sector but it has also become a major step towards relaxing the city's planning regulations and giving power to developers to pursue their own agendas.

This paper is comprised of six parts. Firstly, it provides a critical review of literature on various innovative funding mechanisms and their possible contribution in moving towards a symbiotic planning system. The second part justifies why empirical study in Tehran is conducted. The third part elaborates on the methodology of this research. The third part offers a description of the legal and institutional context of planning policies and practices in Tehran, where this study has been carried out, for the international audience that may not be familiar with it. Then, in the fifth part, the paper critically discusses: the dynamics between the municipality's funding mechanism and 
housing developers, the implications of these dynamics for urban planning, and the location of market-oriented development in Tehran. The final part of the paper concludes with discussing the implications of that particular form of municipal funding to planning and the city's future.

\section{Planning tools and symbiotic planning in a context of welfare state retrenchment}

Based on a systematic review of planning literature, this paper builds an integrated conceptual framework to illustrate how local governments have developed planning tools to deal with uncertainties related to the reduction of money to finance their activities. This paper links welfare state retrenchment to a situation in which policymakers and planning authorities tend to lower the standards of regulations and become entrepreneurial. The label 'entrepreneurial' is used to refer to a type of governance and planning policies and practices that deploy entrepreneurial toolkits and strategies to achieve public policy goals and expanding public revenue.

The relationship between local finances, planning tools and symbiotic planning is investigated in this critical review. The adjective 'symbiotic' that has been used in biology to refer an interaction between two different organisms living in close physical association, or a mutually beneficial relationship between different people or groups, is used in this paper to refer the relationship between planning authorities and developers. This conceptual framework and hypotheses, was tested in an empirical study in Tehran, which results are presented in this paper.

\section{Planning tools as a source of revenue}

In several countries, economic recessions has provided 'a legitimate alibi' for austerity policies and neoliberal narratives which are 'grounded in the virtues of the 
market' to provide a framework for deregulation and the implementation of marketoriented strategies (Branco and Alves, 2020).

The decrease in central government financial assistance to local authorities, associated with the retrenchment of public finance results in there being an increased pressure on municipalities to meet the demands for services made by their residents. In order to address their fiscal needs, municipalities increasingly rely on local sources of revenue; and on other instruments of private finance (Brenner and Theodore, 2008, p. 22). In general, in most countries municipalities are moving from relying only on classic funding sources (e.g. property taxes and intergovernmental transfers) to alternative ways of generating income. In most cities, intergovernmental transfers are reduced and property taxes are unlikely to be sufficient to cover the expenditure of municipalities. To make up this deficit, municipalities search for other ways to access private capital (Slack, 2009). Various means of charging new developments and their developers have been used to generate additional income for municipalities. Charges can be set through negotiation (Section 106 agreement in England, see Crook and Whitehead 2019), regulation (US, see Kim 2020) or even bidding (Brazil, see Sandroni, 2010). It is perceived that these financial compensations have formed new relationships between developers and planning authorities as planning authorities rely on the charges received from developers (Healey et al., 1996; Canelas, 2018).

There are many ways to levy new developments in different countries. Many municipalities and local governments levy charges on developers to provide the facilities that the additional development necessitates or, in some cases, the developer has to provide those services directly, depending on the planning laws of that country (Healey et al., 1996; Needham, 2000; Slack, 2002, 2009; Burgess et al., 2011). These charges can be used to cover the costs of infrastructure such as roads as well as public 
services such as schools but mostly they are not to be used on costs that are for purposes other than those directly related to the specific proposed additional developments (Walls, 2010). These charges were applied under a whole host of different names and are variously known as: planning obligations (Section 106 agreement); a Community Infrastructure Levy (CIL); impact fees, lot levies; and development exactions.

Another common tool to generate income is to capture some or all of the value that public investment, such as public transportation, highway exchange, sewer facilities or parks, generated for private landowners. These measures are again known by different names in different countries such as: land value increment taxes; tax increment financing; betterment taxes; special assessments; and valorisation taxes. This method internalises the positive externalities of public investments by capturing the unearned increase in the value of land adjacent to development of public investment in the area. In terms of equity, this tool addresses the public concern about unfair windfalls to owners of property when values go up as a result of a major infrastructure investment that is paid from general city revenues. Politically, it is useful for the city to capture a share of the positive externalities of financed investment (Slack, 2009).

In addition to above mentioned planning tools, some municipalities relax planning restrictions in a designated area and give developers the right to build beyond the limits of predetermined density or land uses in regulation for a fee. Conditional zoning which is used in the US is a paradigmatic example of this allowing for an increased flexibility. This planning tool permits municipalities to accept a particular land use application which might not be allowed otherwise under existing regulations (Brown and Shilling, 1981). Density bonus is another way to levy charges on developers. Based on this planning tool, developers are permitted to exceed the density limits of planning documents in return for meeting conditions such as preserving a 
historic building or paying extra charges to the municipality (Slack, 2009). Brazil designed a different scheme for additional construction potential: Urban Operation, whereby a developer can build beyond the density regulations in designated zones by purchasing certificates of additional construction potential bonds issued by the City Hall in the Sao Paulo Stock Market Exchange (Sandroni, 2010). Tehran's density bonus is another planning tool of relaxing Floor Area Ratio (FAR) regulations in exchange for a fee.

\section{Symbiotic planning}

The idea of planning being symbiotic has been used in planning studies rarely. The adjective 'symbiotic' refers to a mutually beneficial relationship between different people or groups. Adams and Tiesdell (2010) have used this word to suggest that the relationship between planning and the market is symbiotic rather than dichotomous. They argue there is a synergy between market and urban planning because planners act as market actors whose activities help to construct the market.

This specific mode of planning which addresses the synergies between market and urban planning regulations is proposed by this paper to be called 'symbiotic planning'.

The discussion of the relationship between state and market in the planning process has been discussed widely in the literature. The discussion used to be polarized between whether the state should ignore the market in the process of planning or whether market-led growth was the only way forward. However, recently the discussion has been shifted towards the interactions of market and state regulations rather than merely their opposition. As a result, the focus is on the interrelationships between state and market. 
Some claim that urban planning and the market need to work together in a symbiotic manner for financial and implementing reasons. However, this kind of planning, along with the financial need of local authorities, has had implications for urban planning. Some of the causes and consequences of the shift towards this approach has been discussed in the literature which is discussed below.

In some cases, in order to secure income, urban plans have faced changes to meet market needs and more flexible and negotiable approaches are designed. In this regard, Harvey states that a shift from a 'managerial approach' to 'entrepreneurial forms of actions' (Harvey, 1989, p. 4) has resulted in giving 'a strong role in writing legislation, determining public policies and setting regulatory frameworks' to businesses and corporations who collaborate with state actors (Harvey, 2005, pp. 7677).

Tasan-Kok $(2012$, p. 2) suggests that the reorientation in urban planning has resulted in the replacement of 'rigid and regulatory land-use planning process' with 'a more flexible and negotiable strategic planning process' which supports market-friendly policies in land and property development. She argues that planning authorities would alter the zoning plan in a neoliberal city in order to support the dynamics of propertyled urban development which, for example, would result in the construction of a new large-scale commercial property in the city centre. She argues that 'the local government allows a change in the zoning plan, convinced that a large commercial facility in the centre would enhance the city's competitive advantage. The expected outcome of the land transaction includes a new image for the city, besides rent (and tax) revenue for the local government' (Tasan-Kok, 2012, p. 12).

Similarly, Jou et al. (2012, p. 167), by investigating four case studies in Taipei, observe that "land use codes could be "flexibly" changed to legalise some commercial 
property development in meeting the "market need"'. They argue that the financial deficit of Taiwan's government in the mid-1990s resulted in the need for central government and Taipei municipality to rely on private capital in the provision of public infrastructure. In order to legalise this involvement of private capital in public-private partnership, some laws had to be issued by the central state. In case studies, Jou et al. (2012, p. 154) found that in the decision-making process 'the assumption that private capital is more sensitive to "market needs" and changes than government was', resulted in 'flexibly' changing land use plans to accommodate investors and developers needs. They conclude that 'for private capital, what keeps them continuously cooperating and negotiating with Taipei municipal government is that they can accumulate their own economic capital ... by transferring the public land ... into private profit' (Jou et al., 2012, p. 167).

Although the shift towards 'entrepreneurial mode of governance' (Raco, 2018) has brought financial returns for public and private interests, in the context of Britain, Burgess and Monk (2016) show that how these returns are sensitive to market activities. As their extensive research shows, after 2007 economic downturn and the slowdown in the market, the delivery of planning obligations has been negatively affected as development projects have slowed or stalled completely.

It is obvious that, despite the existence of various and distinctive planning cultures in different countries and regions (Friedmann, 2005), neoliberalisation policies have affected urban planning systems around the world since the late 1970s (TasanKok, 2012). Evidence shows that cities with different political and socio-economic backgrounds are moving towards symbiotic planning which acknowledges the importance of the interactions of market and state regulations. 


\section{Empirical study in Tehran}

In response to the critique of Robinson $(2006,2003,2002)$ and Roy (2009) and their focus on the limitation of the scope of urban theory which is mostly based on US and European cities, this research has chosen Tehran as its focus. To address the dichotomy between Global North cities which are seen as models to generate theory and policy and Global South cities which are perceived as followers and imitators of those Global North cities, Robinson (2006) proposes the concept of 'ordinary cities'. Based on this concept, cities 'are all dynamic and diverse..., [and are] arenas for social and economic life' (Robinson, 2006, p. 1). In a similar way, Roy (2009, p. 820) argues for 'new geographies' of urban theory. She says achieving that, 'requires "dislocating" the EuroAmerican centre of theoretical production; for it is not enough simply to study the cities of the global South as interesting, anomalous, different, and esoteric empirical cases'.

Despite the recent resurgence of interest in studying 'ordinary cities' in comparative studies, Goodfellow (2018) found that the number of studies which explicitly look at cities outside the Global North is very limited. He mentions that 'of the 30 articles included in a 2014 Virtual Issue of the International Journal of Urban and Regional Research on comparative urbanism, few explicitly compare specific cities and only three involve direct comparisons where one or more of the cities is outside the Global North' (Goodfellow, 2018, p. 200). Roy (2009, p. 820) also says that, even in the cases where cities of the Global South are visible in urban theory, they 'are usually assembled under the sign of underdevelopment; that last and compulsory chapter on "Third World Urbanization" in the urban studies textbook'.

The invisibility of cities of the Global South in planning studies is addressed in this study. 


\section{Methodology}

To scrutinise the consequences of the financial dependence of Tehran Municipality on private capital that are captured via development charges throughout the planning system, a qualitative strategy, in which data collection and analysis is based on in-depth analysis of words rather than quantification (Bryman, 2012), has been used. In addition, secondary quantitative data, mostly statistics, was also used to complement the results of the qualitative data ${ }^{\mathrm{i}}$. Besides secondary quantitative data, this research benefits from published and unpublished reports ${ }^{\mathrm{ii}}$, Acts of Iran's Parliament and other planning documents.

Tehran is comprised of 22 districts. In addition to city-level information on how extra construction density has been applied in Tehran, a more focused study was carried out on Tehran's five northern districts: Districts 1, 2, 3, 4 and 5. These five districts have been under increased pressure to develop high-rise residential buildings which exceed construction density limits (Figure 1).

Primary data was collected by conducting 47 semi-structured interviews with housing developers, planners within the public and private sectors, politicians and decision makers in Tehran. Rather than structured interviews, this research employs semi-structured interviews in order to explore beyond the answers of the interviewee and enter into a dialogue with the interviewee (May, 2011). Most of the interviews took place in 2014 and 2015 with a few final ones conducted in 2016.

To better understand how construction density charge has affected the decisions of housing developers, interviews carried out with 15 housing developers. A snowballing strategy was used to contact potential developers who worked across the city and the five mentioned districts to participate in the research.

To trace how tendencies of housing developers have shaped the city and how market-led growth has affected the way in which the city is planned, 32 interviews with 
planners, city council members and municipality officials were carried out. There are two types of planners in Tehran; planners working at the municipality (public sector) and planners practicing at architecture and planning consultant companies (private sector). In Iran, the municipality or the government hires planners in the private sector to prepare the plans and the municipal planners supervise and/or implement those plans. It was necessary to include the viewpoints of both groups.

In each district there was an undertaking to interview at least one municipal planner and one planner from the consultant company which prepared that district's plan. To generate data about various aspects of planning and funding for the city it is necessary to know what the planning and decision-making system is at macro level. Interviews were carried out with key informants who are or used to be members or employees of the Urban Planning and Architecture High Council (UPAHC), Islamic City Council of Tehran (ICCT); Ministry of Roads and Urban Development (MRUD); Tehran Municipality and other relevant institutions.

An explanation-building technique (Yin, 2009) is used to analyse the data and to build an explanation as to how the construction density charge has affected the planning system and spatial development of Tehran. Elements of explanations stem from research objectives, literature review and interviews. A set of themes is prepared, to order and analyse the data and then an appropriate narrative for the analysis is sought.

\section{Contextualising}

\section{Tehran Municipality's (in)dependence}

After the Iran-Iraq war in the late 1980s, the country was under economic pressure and went through deregulation, privatization and cut in subsidies, to reduce costs and stimulate growth (Pourzal, 2008). Financial independence of municipalities 
was perceived as one of the major steps towards downsizing government. Firstly, in the Budget Bill of 1983, parliament approved that Iran's Government should start to phase out its financial assistance to municipalities (IPI, 1983). Then, in the First 5-year Development Plan of Iran (1990-1995) it was approved that, by the end of the time span of the plan, municipalities should be financially self-sufficient (IPI, 1990).

Since the 1990s, municipalities in Iran have been under economic pressure to become financially self-sufficient. Tehran Municipality developed planning tools to generate income to manage the city (Azizi, 2005) such as changing function of buildings for a fee, privatisation of public lands, increasing property taxes and privatising some services and sectors of (Izadi, 2008, p. 86). However, the major generator of revenue became the fees obtained from developers to allow them to increase the FAR of their buildings (Azizi, 2002) which is called the excess construction density charge (ECDC).

Development related charges (including ECDC) have generated a considerable amount of income for the Tehran Municipality. Based on an internal unpublished report provided by one of the interviewees, between 2002 and 2012 at least $75 \%$ of Tehran Municipality's income came from the development charges (see Table 1). As proven in Table 2, which presents the share of the ECDC in the total development charges of Tehran Municipality's income between 2002 and 2012, ECDC is one of the main contributors to the development charges.

Some of the examples of other development charges mentioned in this report are fees for construction permit, compensation for violating construction codes, compensation for balconies and overhangs, compensation for not providing mandatory parking spaces and etc. 
Although, based on Table 2, the percentage of income coming from the ECDC has fallen since 2010 - an interviewee explained that the real amount of cash income from this source has been growing each year. The reason behind the decrease of the portion of the ECDC in total development charges is because of the growth or emergence of the other categories of development charges:

'Here, you might think that the share of the ECDC is decreasing in recent years compared to 2009. But if you look closely you will see that other codes are growing or new income codes are emerging [...] for example a row is added as a charge for construction of a private swimming pool! Which is mainly for luxury buildings'.

Interviewed experts believe that, although charging for the construction of new developments is necessary, the municipality should not rely on it as it is an unsustainable source of income. The concept of 'unsustainable', was used to refer something that cannot continue at its current rate because, as pointed out by them, the amount of construction activity in a year is not consistent and could vary a lot from one year to another. In this regard one of the interviewees who used to work at the Budget Office of the Tehran Municipality explained that:

'The municipality's budget has various income codes, they did not categorise the income sources into sustainable and unsustainable but it is possible to identify which ones are unsustainable. Construction related codes are unsustainable sources $[\ldots]$ as they are not constant and might be less in one period and more in another period depending on the property market.'

According to this interviewee's research on the municipality budget for the year 2015:

' $70 \%$ of the income of the Tehran Municipality comes from unsustainable sources. From 17,460 billion toman proposed income for 2015 financial year, almost 12,000 
billion, comes from unsustainable sources including ECDC and other construction related incomes.'

He explained that the only sustainable sources of income for the Tehran Municipality are VAT and property tax. However, the amount generated from these sources is limited:

'In the year 2015, in total 3,200 billion toman of municipal income came from VAT, which is only $18 \%$ of its total income. [...] The income coming from property tax in year 2015 was around 1 to $1.5 \%$ [...] while in other countries 40 to $50 \%$ of the municipal income would come from property tax $[\ldots]$.'

There is no will to increase property tax as a sustainable source of income. The resistance of the Tehran Municipality to increase property tax and reduce the income coming from construction is elaborated by one of the interviewees:

'The municipality has got used to this system $[\ldots]$ in this way it has to deal with only 20 to 50 thousand people who are involved in large construction and they are willing to give the municipality the money rather than dealing with the 3 million residents of Tehran.'

All of the development related charges (including ECDC) are financial contributions (as opposed to in-kind contributions in countries like Britain) to finance part of the operating and capital expenditures of the municipality.

\section{The role of construction density: from a planning to a funding tool}

Construction density (FAR) has been used as a planning tool in the Iranian cities to control population growth of neighbourhoods. However, by relaxing construction density limits in exchange for a fee, this tool was transformed to a funding tool. As a result, the concept of optimum population considered by the plans to provide public infrastructure becomes irrelevant. 
The Tehran Comprehensive Plan (TCP), prepared in 1968, was the city's first official development plan and it recognised FAR as a planning tool in order to, amongst other things, control the population of the city. This plan proposed a maximum population of 5.5 million for Tehran in an area of $715 \mathrm{~km}^{2}$, to be achieved in a 25 -year time span. To bring about this goal, TCP proposed different construction density (FAR) limits throughout the city, ranging from low to high density.

However, after the Islamic revolution in 1979, the TCP proposals, including construction density limits, were altered by both the municipality and the Government. Instead, in respect of construction density, a single target of $120 \%$ FAR on a maximum $60 \%$ of land area was set for the whole city. This means one could build a two-storey building on a maximum $60 \%$ of land area.

Later, in 1984, in order to encourage construction and redevelopment in the southern part of the city, known as the 'deteriorated neighbourhoods', the city was divided into two construction density zones. Construction densities of a maximum of $120 \%$ (two floors on $60 \%$ of land) and $180 \%$ (three floors on $60 \%$ of land) were considered for areas located on the north side of Enghelab Street ${ }^{\mathrm{iii}}$ and the south side of this street respectively (Tehran Municipality, 1991).

Later, in 1991, the Urban Planning and Architecture High Council ${ }^{\text {iv }}$ (UPAHC) passed the 'Increasing Density and High-Rise Building Act' which allowed a maximum of $25 \%$ increase in the population and construction density of some cities (UPAHC, 1991). Based on a previous Act approved by the UPAHC in 1987, municipalities were permitted to capture the value added to properties because of the increase in their construction density (UPAHC, 1987). These two Acts provided the legal basis for the Tehran Municipality to charge applicants who wanted to build property at a construction density higher than $120 \%$ (two-storey on $60 \%$ of land). This is despite the 
public belief that Karbaschi, Mayor of Tehran between 1989 and 1998, introduced the ECDC.

Since the approval of the above mentioned legislations, to build on a land or redevelop a building taller than two floors ( $120 \%$ of $60 \%$ of a land parcel) the developer must pay the ECDC. Based on statistical data gathered by the Statistical Centre of Iran, more than $98 \%$ of the construction permits granted in Tehran are to build buildings with more than two floors (SCI, 2011, 2012, 2013, 2014) which means more than $98 \%$ of construction applicants should pay for the extra FAR. This is a legal payment as long as the granted extra construction density is in line with FAR limits of the zone in the city and district's plans. However, the financial needs of the Tehran Municipality encouraged the practice of granting development permits beyond the construction density limits of official plan:

'To build or re-develop land on more than two floors the developer must pay the construction density charge which is a legal payment if the construction density is in line with the Tehran's plan. The problem is that the municipality grants extra construction density beyond the plan by negotiating with the investors.'

By law, a commission called Commission No. $5(\mathrm{CN} 5)^{\mathrm{v}}$ should decide about the applications asking for excess construction density beyond the limits of the zone. However, due to sheer number of applicants, CN5 bestowed decision-making power on the Tehran Municipality and the district's municipalities for a long time. As a result, Agreements Commissions were formed in all the district's municipalities to reach agreements with the applicants. During the 1990s, many applicants could get a construction permit to build high-rise buildings through Agreement Commissions. This practice caused the transformation of the urban landscape very quickly (Madanipour, 2011, p. 86) and raised public opposition because there was not adequate infrastructure 
in place; this was as a result of the imposed construction density and increased population (Madanipour, 1998, p. 79).

In the late 1990s, to address the physical and social consequences of the arbitrary granting of construction density, both Commission No. 5 (CN5) and the government (the Urban Planning and Architecture High Council- UPAHC) tried to intervene in the process by introducing directives. CN5's directives (Directives 269 and 329) were for buildings up to five floors. These directives introduced a matrix for maximum FAR increase based on the area of a land and the width of the street where the land is located.

The UPAHC directive was to regulate the way tall buildings (with six or more storeys) were constructed without any regulation during the 1990s. The directive was approved to set some general rules such as the minimum width of a passage, the minimum space between blocks and unblocking access of winter sunlight to other buildings.

The price to be paid for each square meter of extra construction density is calculated by a formula. This formula in calculating the payable charge considers the transaction value of the property based on the Ministry of Economic Affairs and Finance's booklet and other factors (e.g. location of the plot in the district) to be able to capture part of the extra value generated as result of the extra density. As described by an interviewee who was involved in design of the formula:

\footnotetext{
"The formula was designed in a way that the amount to be paid for construction density is very high in expensive areas [...]. This was because we wanted to move the wealth in the city towards the south and poorer areas."
}

Despite the approved regulations and formula, as mentioned by interviewees, it has been always a resistance from some stakeholders (not only developers and investors 
but also municipality) towards disciplining the process of granting and the pricing of the construction density bonus which will be discussed further in this paper.

\section{The Tehran Plan}

As mentioned above, after the Revolution, Tehran did not follow TCP which was approved before the revolution. During the late 1980s and 90s, several attempts were made to control Tehran's development but they were mostly unsuccessful (for more information see Madanipour, 2006).

During this time the city was growing and changing fast, based on the municipality's discretion and without any effective scrutiny over its performance. Concerned experts in the field of urban planning established a professional group (called Tehran's Expert Group). In 2002, they made a proposal to the Tehran Municipality to prepare a new plan for the city (Farivar Sadri, 2014).

Experts' proposal was accepted; thus 22 consultant companies were commissioned to carry out analysis and prepare plans for each district of the city. A synthesiser consultant company, ParsBoom Consulting Engineers, was also commissioned to oversee the work of those 22 consultant companies (Farivar Sadri, 2014). A joint institution, the Tehran City Planning Agency (TCPA), was also created to facilitate collaboration between Tehran Municipality, Government and consultant companies.

It was agreed to prepare a Structural-Strategic Plan at city level (called Tehran Structural-Strategic Comprehensive Plan) instead of using the traditional comprehensive planning approach. At local level, District Plans (DPs) and, at a more micro level, Area Action Plans and Thematic Plans (AAPs and TPs) replaced previous detailed plans (land use plans) (for more information see Majedi, 2012). 
The Tehran Structural-Strategic Comprehensive Plan (TSSCP) was approved in 2007. However, it took another five years to approve the local level plans called District Plans (DPs) of each district. The reasons behind this delay is discussed later.

TSSCP is a zoning plan which considers different construction density limits for different zones of the city. The construction regulation section of the TSSCP provided a prescriptive and detailed information on construction density limits of different zones of the city. Interviewed planners and developers believe that the approval of the plan has reduced the negotiating power of the developers in getting what they want in terms of excess construction density:

'At the moment, the selling of extra construction density is not as it was before. Until 2013 they used to sell construction density massively. But now, regulations are taken more seriously by the municipality.'

However, the plan itself has faced waves of change to increase construction density of some zones for financial reasons which will be discussed below.

\section{Analysis}

\section{Symbiotic relationship between Tehran Municipality and housing developers}

As mentioned previously, $75 \%$ of the Tehran Municipality income comes from development charges; therefore, the municipality is dependant on the construction sector and its agents. Amongst all other kinds of construction activities in Tehran, housing became a much larger player. $80 \%$ of the total construction activities in Tehran Province between 2011 and 2015 were for the construction of residential buildings (Bank-e Markazi, 2016, p. 17). Based on construction permits issued between 1996 and 2000, the World Bank (2004, p. 126) reports that $86 \%$ of new housing in Tehran was 
built by the private sector. As a result, to a large extent, the income of the Tehran Municipality relied on housing construction and its private sector developers.

Between 70 and $80 \%$ of private housing developers in Tehran are either individual developers or small construction companies. Only $20 \%$ of the housing developers in Tehran are major development companies who are primarily interested in large-scale developments such as high-rise buildings. As mentioned by interviewed developers, the main reason behind why individual developers are the main participants in housing construction is the size of land parcels and as a result the size of development projects in Tehran.

The main goal of private sector developers in Tehran, as anywhere else, is 'to accumulate profit by producing buildings whose realized value is greater than the cost of development' (Henneberry, 1999, p. 1446). Developers do not get involved in the production of housing unless they are confident that they can make enough profit. As mentioned by interviewed developers, the performance of the property market, the costs of construction, the banks' interest rates and the political stability of the country all play a crucial role in a developer's decision about whether it is a good time to invest in housing in Tehran or not. In this context a developer said:

'[...] We do a simple math; we calculate our total costs and returns to find out the size of our profit. Then we compare this profit to the banks' interest rate. If the construction generates more profit for us than putting our money in the banks, then we do it.'

Due to rising land prices in Tehran, especially in Districts 1 to 5 (affluent parts of the city), the construction density limit of a land parcel contributes decisively to the decisions of developers. If the construction density of a land is less than a certain amount, which would differ in each case, it would no longer be economically justifiable 
for the developer to build on that land. One of the developers explained the importance of the construction density limit on his decision:

\footnotetext{
'Normally, the maximum construction density of land is one of the very important parameters that you should consider when you want to build either for personal use or for business. Let me give an example. It has been three years since we have been thinking about redeveloping my father's house [...]. When we did the maths we saw that it was not worth investing in redeveloping it $[\ldots]$ because if we deposit our money in the bank we could get $20 \%$ profit which is the same as the profit that we could get by redeveloping that land. This is because they gave us a maximum construction density of $240 \%$ which means four floors which does not have an economic justification. Because the land price will be divided into four, this makes each flat more expensive than the area's average price and it will be hard to sell them $[\ldots] \cdot$
}

It is a common practice for developers to try to increase the construction density of the building that they want to construct as much as possible. By doing so they can increase the saleable area of the building. However, individual developers and small construction companies are mostly able to increase the construction density for a maximum of just two more floors beyond FAR limits of an area while large development companies would try to increase the construction density as much as possible. This is because large-scale development companies are in a better bargaining position with the municipality as they have access to resources and the municipality simply needs to secure its income.

Whilst for developers, maximising profit is the prime goal, for the municipality increasing the amount of its income from construction is one of its main priorities. In addition to being responsible to upkeep of the city and provide various services, the municipality is responsible for implementation of large-scale projects like Tehran's metro system and the renovation of the bus system which are costly. 
To keep developers in business, the municipality tries to make construction activity attractive for them so that it, in turn, can generate its own income from those activities. In other words, the Tehran Municipality needs to be responsive to the requirements of the construction sector as it depends on them so much.

\section{The role of planners and the impacts of symbiotic planning}

The symbiotic relationship between the municipality and housing developers has affected the process of preparing, approving and updating the recent plan of Tehran. The Tehran plan has experienced significant alterations and interventions to increase the municipality's income by accommodating property developers' interests. Following paragraphs scrutinises the implication of this symbiotic relationship on the Tehran Plan.

The first phase of the plan (1:10000 plan) was prepared by consultant companies under the supervision of the Tehran City Planning Agency (TCPA). This plan was prepared based on technical considerations such as the capacity of the road networks and public amenities in an area rather than being based on socio-economic considerations. In Iran, planners working in consultant companies do not see themselves as what Adams and Tiesdell (2010), in the British context, call market actors who play a role in affecting and shaping the market. They rather see themselves as technocrats and perceive urban planning as a scientific activity. This culture goes back to the 1970 s when these firms started to emerge. Within these firms urban planning is seen as 'architecture and engineering on the scale of a whole city' (Mashayekhi, 2018, 13).

The first phase of the plan was prepared in a sphere disconnected from the reality of the symbiotic dynamics that exist between the municipality and the housing developers. A planner said: 
'An academic obsession with the relationship between the width of passages and the height of buildings has resulted in the production of a plan which does not care about real forces, such as the real estate market in the city.'

Neither the municipality nor the developers were pleased with the economic consequences that the first phase of the plan could have for them. Nevertheless, the first phase of the plan was approved in 2008. However, the preparation of the second phase (1:2000 plan) was directed in such a way to give authority to the Tehran Municipality by dismantling the TCPA and dismissing the 22 consultant companies. The Architecture and Urbanism Department (AUD) of the Tehran Municipality became the organisation responsible for preparing the 1:2000 District Plans (DPs) with the technical assistance of the synthesiser consultant company. Tehran Municipality used this opportunity to impose its financial aspirations on the plan. The prepared plan which was supposed to be produced based on the 1:10000 plan, had many contradictions with the first phase. For the municipality, it was important to encourage the developers to invest in the construction sector. That is why the plan was prepared in such a way as to consider the financial profits of developers.

The government of the time, instead of scrutinising the DPs to make sure that it was in accordance with the 1:10000 plan, issued a directive to intervene in the plan by increasing the construction density of some zones. On the surface, it was said that this decision of the government was in order to increase the housing supply and reduce the price of the housing for all residents. However, the interviewed planners believe that this decision had economic justification for the government. As stated by one of the interviewees:

'Ahmadinejad's government was experiencing negative economic growth. By stimulating the property market he wanted to conceal the inflation.' 
The Tehran Municipality, whose income would be raised by this, supported this directive. Here we can see that government, the municipality and developers were all on the same side and would benefit from a plan with relaxed regulations on construction density.

In addition to the aforementioned alterations and the imposing of marketoriented measures to the plan, there was a time gap of five years between approving the 1:10000 plans and the 1:2000 DPs. As mentioned by planners working in the consultant companies, the plan was ready in 2010 but the municipality intentionally delayed the process because:

'The municipality was aware of the consequences of implementing the new plan; the municipality knew that its income would be decreased $[. .$.$] and was looking for$ a way to solve this problem and at the same time granted as many construction permits as possible.'

Many of the developers and landowners became aware of the future construction density of their parcels of land and rushed to get construction permits based on previous regulations before the approval of the new plan. One of the planners working in a consultant company explained that:

'The plan was ready in 2010 but the municipality intentionally delayed the process.

[...] Many developers got their construction permits at that time. Many of the towers under construction at the present time got permission at that time.'

Studying the number of construction permits issued each year shows that 2011 the peak was reached in the number of permits (Figure 3). One of the interviewees pointed out that:

'If you look at the statistics of the construction permits in 2010, 2011, 2012 and even 2013 and part of 2014 you will notice the increase in the number of permits, 
the increase in the floor area permitted. [...] The municipality's income grew a lot in those years.'

This five-year gap was an opportunity for the developers to get permissions and for the municipality to generate revenue before the implementation of the new zoning plan. As a result of the permits granted during these gap years before the dissemination of the 1:2000 plan, it was already out of date and many zones had already changed. The plan needed to be updated to address those changes. Although some modifications were unavoidable, the municipality used the opportunity to further satisfy its financial plans by changing zones and increasing construction density. As stated by a member of Islamic City Council of Tehran:

'This (amending the errors) became an excuse for the municipality to generate income. This was a way for the municipality to change the zones. The district's municipalities were under pressure to generate income so they changed the zones of large parcels of land to zones which were more profitable for the municipality.'

For the municipality, making construction appealing to the developers by changing the plan was the most important thing. There are cases that show that the modification of the plans was more concerned with the market rather than the benefit of the city. Although developers have no direct contribution in the process of planning, their interest has affected the preparation and implementation of plans.

\section{Geographies of symbiotic planning development}

Compromising the construction density regulations of the plan has been prevalent in certain areas of the city more than in others. Areas with a higher surplus in the housing construction investment have experienced the construction density regulations being dismissed more frequently. As stated by a planner: 
'In the areas where the price of land and real estate are high, ignoring the plans by the municipality to generate money is more probable.'

The housing developers with strong financial resources prefer to work in expensive areas which are mostly located in the northern districts. These districts have experienced development of buildings exceeding the construction density limits of the plan. As a result, these are the districts that have generated income for the Tehran Municipality. A planner in Tehran Municipality explained that most of the municipality's income comes from the affluent northern and western districts of the city where housing and commercial construction are prosperous. He says:

\footnotetext{
'We have four districts that provide more than $60-70 \%$ of the municipality's income. These are districts 1,3 , north section of 2 and $22^{\mathrm{vi}}$. [...]. North section of district 5 is not bad too but not as good as districts 1, 2, 3 and 22. [...]. In District 4 only Pasdaran ${ }^{\text {vii }}$ is good but in general District 4 is the most populated district with many deprived areas which impose a lot of expenditure on the municipality.'
}

Consequently, alterations in the construction density of zones during and after the planning process have happened there more often. A piece of research (Iran's Urban and Architecture Centre, 2016) confirms that Districts 1, 2, 3, 4 and 5 have experienced a lot of zone changes by the Tehran Municipality after the approval of the TSSCP (see Figure 3). The researcher involved in preparation of that study explained:

'The zones of Districts 1, 2, 3, 4 and 5 have changed a lot. We should leave aside the spike of the diagram's bar in Regions 18, 21 and 22 because the first two are industrial districts and the change in their zones were to free up preserved land for industrial uses and the story of District 22, as you may know, is very different. I should mention that in Region 4, like Region 21, many of the changed zones are related to freeing up preserved land [...]. The construction density of the northern regions increased as the municipality knew that these are the regions where it could generate money, not in the southern regions.' 
The Tehran Municipality's income is mostly coming from these districts and as a result, symbiotic considerations were more prevalent in these areas.

\section{Conclusion}

Most of local governments and municipalities are increasingly reliant on the financial resources of private developers and investors to deal with economic uncertainties related to the reduction of funds due to austerity measurements in place (Brenner and Theodore, 2008). Thus, the relationship between them and the market has become a symbiotic relationship (Adams and Tiesdell, 2010) with mutual benefits for both planning authorities and developers.

Now that these two need to work together in a symbiotic manner, the implications of this relationship for urban planning should be addressed carefully. As discussed in literature, urban plans have been faced changes to meet market needs and more flexible and negotiable approaches are designed to support market-friendly policies (Tasan-Kok, 2012; Jou et al., 2012) which has consequences for the future of the cities.

By careful analysis of the collected data on development and planning processes in Tehran, this paper contributes to the literature from two different perspectives. First, it provides a new case study of density bonus as a planning tool to generate income for the municipality. This allows a better understanding of the planning tools on governance of the city. Second, it tackles the issue of how municipal financial tools (such as density bonus) affect planning decisions.

In the case of Tehran, the financial dependence of Tehran Municipality on income generated from increasing construction density paid by developers (through ECDC) has led to a symbiotic relationship between Tehran Municipality and developers. The result is a planning policy that is responsive to property market 
interests rather than the city's strategic needs or the public interest. Although attempts have been made to harness this market-led growth by introducing a new plan for the city, massive alterations and interventions on the plans happened to secure the benefit of developers and the municipality's income.

It is my conviction that the consequences of symbiotic mode of planning should not be ignored in any city including Tehran. The ECDC has assisted the Tehran Municipality to achieve financial independence from central government and has helped it to have some degree of autonomy. However, this has made the municipality dependent on the construction sector and its agents, such as housing developers. Without providing an alternative source of income for the Tehran Municipality it is unlikely to have much success in a cogent planning for Tehran.

i Quantitative secondary data on some of the issues discussed in this article are not always available or are not available for public use because of the sensitivity of the issues.

ii In some occasions this research relies on unpublished reports which are either internal reports or not published due to the controversies around the subject.

iii Enghelab Street (and its western extension which is Azadi Street) goes through centre of the city and divides the city into north and south.

iv UPAHC has the highest decision-making authority on urban planning matters at national level and is responsible for the approval of any major urban plan policy.

v Commission No. 5 consists of representatives of various governmental and public organisations with a stake in urban planning (IPI, 1986)

vi District 22 had been annexed to Tehran and became an official district of the Tehran Municipality in the 2000s. A lot of green land in this district has been released for development recently and its development trajectory is quite different from other districts of the city. That is why this district was not included in this research.

vii Pasdaran Street is located on the western side of District 4 


\section{References}

Adams, D., Tiesdell, S., 2010. Planners as Market Actors: Rethinking State-Market Relations in Land and Property. Planning Theory \& Practice. 11, 187-207.

Azizi, M., 2005. The Challenges of Urban Development and Density in Tehran. Proceedings of the International Conference for Integrating Urban Knowledge \& Practice, Gothenburg.

Azizi, M., 2002. Naghsh va Jaygah-e Tarakom-e Sakhtemani Dar Tose'e-ye Shahri, in: Majmooeh Maghalat-e Avalin Seminar-e Sakht va Saz Dar Payetakht. Presented at the Avalin Seminar-e Sakht va Saz Dar Payetakht, Daneshgah Tehran, Tehran.

Bahl, R., 2008. Opportunities and Risks of Fiscal Decentralisation: A Developing Country Perspective, in: Ingram, G.K., Hong, Y. (Eds.), Fiscal Decentralization and Land Policies. Lincoln Institute of Land Policy, Cambridge [Mass.].

Bird, R.M., Slack, E., 2007. Taxing Land and Property in Emerging Economies: Raising Revenue ... and More?, in: Ingram, G.K., Hong, Y. (Eds.), Land Policies and Their Outcomes. Lincoln Institute of Land Policy, Cambridge, Mass.

Brenner, N., Theodore, N., 2008. Cities and the Geographies of "Actually Existing Neoliberalism," in: Brenner, N., Theodore, N. (Eds.), Spaces of Neoliberalism: Urban Restructuring in North America and Western Europe. Blackwell, Malden, Mass.

Brown, F.O., Shilling, S.L., 1981. Conditional Zoning in Virginia. University of Richmond Law Review. 16, 117-137.

Bryman, A. (2012). Social research methods (4th ed). Oxford University Press.

Burgess, G., \& Monk, S. (2016). Delivering planning obligations - are agreements successfully delivered? In T. Crook, J. Henneberry, \& C. M. E. Whitehead (Eds.), Planning gain: Providing infrastructure \& affordable housing. John Wiley \& Sons Inc.

Burgess, G., Monk, S., Whitehead, C., 2011. Delivering local infrastructure and affordable housing through the planning system: the future of planning obligations through Section 106. People Place Policy Online. 5, 1-11.

Canelas, P. (2018). Challenges and Emerging Practices in Development Value Capture. In J. Ferm \& J. Tomaney (Eds.), Planning practice: Critical perspectives from the UK. Routledge. 
CBI [Central Bank of Iran], 2016. Natayej-e Barresi-ye Faaliathay-e Sakhtemani-ye Bakhsh-e Khosoosi dar Manategh-e Shahri-ye Ostanhay-eMokhtalef-e Iran/Sheshmaheh-ye Aval-e Sal-e 1394. Central Bank of The Islamic Republic of Iran, Tehran.

Crook, T., Henneberry, J., \& Whitehead, C. M. E. (2016). Planning gain: Providing infrastructure \& affordable housing.

Crook, A. D. H. (Tony), \& Whitehead, C. (2019). Capturing development value, principles and practice: Why is it so difficult? Town Planning Review, 90(4), 359-381.

Farivar Sadri, B., 2014. Tahavolat tarhrizi shahri Iran dar doran moaser. Azarakhsh Publications, Tehran.

Friedmann, J., 2005. Globalization and the emerging culture of planning. Progress in Planning. $64,183-234$.

Goodfellow, T., 2018. Seeing Political Settlements through the City: A Framework for Comparative Analysis of Urban Transformation: Seeing Political Settlements through the City. Development and Change. 49, 199-222.

Harvey, D., 2005. A brief history of neoliberalism. Oxford University Press, Oxford ; New York.

Harvey, D., 1989. From Managerialism to Entrepreneurialism: The Transformation in Urban Governance in Late Capitalism. Geografisca Annaler: Series B Human Geography. 71, 317.

Healey, P., Barrett, S.M., 1990. Structure and Agency in Land and Property Development Processes: Some Ideas for Research. Urban Studies. 27, 89-103.

Healey, P., Purdue, M., Ennis, F., 1996. Negotiating development: Planning gain and mitigating impacts. Journal of Property Research. 13, 143-160.

Henneberry, J., 1999. Convergence and Difference in Regional Office Development Cycles. Urban Studies. 36, 1439-1465.

Heurkens, E., Hobma, F., 2014. Private Sector-led Urban Development Projects: Comparative Insights from Planning Practices in the Netherlands and the UK. Planning Practice \& Research. 29, 350-369.

Ihlanfeldt, K.R., Shaughnessy, T.M., 2004. An empirical investigation of the effects of impact fees on housing and land markets. Regional Science and Urban Economics. 34, 639-661.

Ingram, G.K., Hong, Y. (Eds.), 2010. Municipal revenues and land policies. Lincoln Institute of Land Policy, Cambridge, Mass. 
IPI [Islamic Parliament of Iran], 1990. Barnameh-ye Aval-e Tosea-ye Eghtesadi, Ejtemaei, Farhangi-ye Jomhoori-ye Eslami-ye Iran.

IPI [Islamic Parliament of Iran], 1983. Ghanoon-e Boodgeh-ye Sal-e 1362 Kol-e Keshvar (Country's Budget Bill of 1983).

Izadi, M.S., 2008. A study on city centre regeneration: a comparative analysis of two different approaches to the revitalisation of historic city centres in Iran. Newcastle University, Newcastle.

Jou, S.-C., Lund Hansen, A., Wu, H.-L., 2012. Accumulation by Dispossession and Neoliberal Urban Planning: 'Landing' the Mega-Projects in Taipei, in: Tasan-Kok, T., Baeten, G. (Eds.), Contradictions of Neoliberal Planning, GeoJournal Library. Springer Netherlands, Dordrecht.

Kim, M. (2020). Upzoning and value capture: How U.S. local governments use land use regulation power to create and capture value from real estate developments. Land Use Policy, 95, 104624.

Madanipour, A., 2011. Sustainable Development, Urban Form, and Megacity Governance and Planning in Tehran, in: Sorensen, A., Okata, J. (Eds.), Megacities : Urban Form, Governance, and Sustainability, CSUR-UT Series: Library for Sustainable Urban Regeneration. Springer, Tokyo ; London.

Madanipour, A., 2006. Urban planning and development in Tehran. Cities. 23, 433-438.

Madanipour, A., 1998. Tehran: the making of a metropolis, World cities series. Wiley, Chichester, West Sussex, England; New York.

Madanipour, A., 1996. Design of urban space: an inquiry into a socio-spatial process. Wiley, Chichester; New York.

Majedi, H., 2012. Theory of Preparing Structure-Strategic Plans. Hoviatshahr. 6, 17-26.

Mashayekhi, A. (2019). The 1968 Tehran master plan and the politics of planning development in Iran (1945-1979). Planning Perspectives, 34(5), 849-876.

May, T. C. (2011). Social research: Issues, methods and process. Open University Press.

Needham, B., 2000. Land taxation, development charges, and the effects on land-use. Journal of Property Research. 17, 241-257.

Peck, J., 2012. Austerity urbanism: American cities under extreme economy. City 16, 626-655.

Pourzal, R., 2008. Populism and Neoliberalism in Iran. Dollars Sense 18-21. 
Raco, M. (2018). Private Consultants, Planning Reform and the Marketisation of Local Government Finance. In J. Ferm \& J. Tomaney (Eds.), Planning practice: Critical perspectives from the UK. Routledge.

Robinson, J., 2006. Ordinary cities: between modernity and development, Questioning cities. Routledge, London; New York.

Robinson, J., 2003. Postcolonialising Geography: Tactics and Pitfalls. Singapore Journal of Tropical Geography. 24, 273-289.

Robinson, J., 2002. Global and world cities: a view from off the map. International Journal of Urban and Regional Research. 26, 531-554.

Roy, A., 2009. The 21st-Century Metropolis: New Geographies of Theory. Regional Studies. $43,819-830$.

Sandroni, P., 2010. A New Financial Instrument of Value Capture in São Paulo, in: Ingram, G.K., Hong, Y. (Eds.), Municipal Revenues and Land Policies. Lincoln Institute of Land Policy, Cambridge, Mass.

Sanyal, B., 2005. Hybrid Planning Cultures: The Search For The Global Cultural Commons, in: Sanyal, B. (Ed.), Comparative Planning Cultures. Routledge, New York.

SCI [Statistical Centre of Iran], 2015. Etelaat-e Parvaneh-haye Sakhtemani Sadre Shodeh Tavasot-e Shahrdari-haye Keshvar 1393. Statistical Centre of Iran, Tehran.

SCI [Statistical Centre of Iran], 2014. Etelaat-e Parvaneh-haye Sakhtemani Sadre Shodeh Tavasot-e Shahrdari-haye Keshvar 1392. Statistical Centre of Iran, Tehran.

SCI [Statistical Centre of Iran], 2013. Etelaat-e Parvaneh-haye Sakhtemani Sadre Shodeh Tavasot-e Shahrdari-haye Keshvar 1391. Statistical Centre of Iran, Tehran.

SCI [Statistical Centre of Iran], 2012. Etelaat-e Parvaneh-haye Sakhtemani Sadre Shodeh Tavasot-e Shahrdari-haye Keshvar 1390. Statistical Centre of Iran, Tehran.

SCI [Statistical Centre of Iran], 2011. Etelaat-e Parvaneh-haye Sakhtemani Sadre Shodeh Tavasot-e Shahrdari-haye Keshvar 1389. Statistical Centre of Iran, Tehran.

Singell, L.D., Lillydahl, J.H., 1990. An Empirical Examination of the Effect of Impact Fees on the Housing Market. Land Economics. 66, 82.

Skaburskis, A., Qadeer, M., 1992. An Empirical Estimation of the Price Effects of Development Impact Fees. Urban Studies. 29, 653-667.

Slack, N.E., 2009. Guide to municipal finance. UN-Habitat, Nairobi. 
Slack, N.E., 2002. Municipal finance and the pattern of urban growth, Commentary (C.D. Howe Institute). C.D. Howe Institute, Toronto.

Tasan-Kok, T., 2012. Introduction: Contradictions of Neoliberal Urban Planning, in: TasanKok, T., Baeten, G. (Eds.), Contradictions of Neoliberal Planning, GeoJournal Library. Springer Netherlands, Dordrecht.

Tasan-Kok, T., Baeten, G. (Eds.), 2012. Contradictions of Neoliberal Planning, GeoJournal Library. Springer Netherlands, Dordrecht.

Tehran Municipality, 1991. Tehran va Tarakom. Tehran Municipality, Tehran.

Tiesdell, S., Allmendinger, P., 2005. Planning Tools and Markets: Towards an Extended Conceptualisation, in: Adams, D., Watkins, C., White, M. (Eds.), Planning, Public Policy \& Property Markets. Blackwell Pub., Oxford, UK; Malden, MA.

TMICTO, Tehran University, 2011. Atlas of Tehran Metropolis, 1st ed. Tehran Municipality Information \& Communication Technology Organisation, Tehran.

UPAHC [Urban Planning and Architecture High Council], 1991. Zavabet va Moghararaat-e Afzayesh-e Tarakom va Bolandmartabeh Sazi.

UPAHC [Urban Planning and Architecture High Council], 1987. Zavabet-e Mantagheh-bandi va Taiin-e Tarakom-haye Sakhtemani va Karbari-ye Arazi

Walls, M., 2010. , in: Ingram, G.K., Hong, Y. (Eds.), Municipal Revenues and Land Policies. Lincoln Institute of Land Policy, Cambridge, Mass.

World Bank, 2004. Islamic Republic of Iran, Ministry of Housing and Urban Development, Strategies for the housing sector (No. 28983). World Bank, Washington DC.

Yin, R. K. (2009). Case study research: Design and methods (4th ed). Sage Publications.

Table 1. Share of the development charges in the total income of the Tehran Municipality between 2002 and 2012. Source: (Unpublished confidential internal document) 


\begin{tabular}{|l|l|l|l|l|l|l|l|l|l|l|l|}
\cline { 2 - 9 } \multicolumn{1}{|l|}{2002} & 2003 & 2004 & 2005 & 2006 & 2007 & 2008 & 2009 & 2010 & 2011 & 2012 \\
\hline $\begin{array}{l}\text { Share of } \\
\text { development } \\
\text { related } \\
\text { charges }\end{array}$ & $86 \%$ & $83 \%$ & $80 \%$ & $79 \%$ & $84 \%$ & $86 \%$ & $87 \%$ & $82 \%$ & $79 \%$ & $80 \%$ & $75 \%$ \\
\hline
\end{tabular}

Table 2. Share of the ECDC in the total development charges of Tehran Municipality's income between 2002 and 2012. Source: (Unpublished confidential internal document)

\begin{tabular}{|l|l|l|l|l|l|l|l|l|l|l|l|}
\cline { 2 - 9 } \multicolumn{1}{l|}{ Year } & 2002 & 2003 & 2004 & 2005 & 2006 & 2007 & 2008 & 2009 & 2010 & 2011 & 2012 \\
\hline $\begin{array}{l}\text { Share } \\
\text { of the } \\
\text { ECDC }\end{array}$ & $70 \%$ & $73 \%$ & $62 \%$ & $76 \%$ & $73 \%$ & $75 \%$ & $77 \%$ & $77 \%$ & $55 \%$ & $45 \%$ & $44 \%$ \\
\hline
\end{tabular}

Figure 1. Locations of Districts 1, 2, 3, 4 and 5 


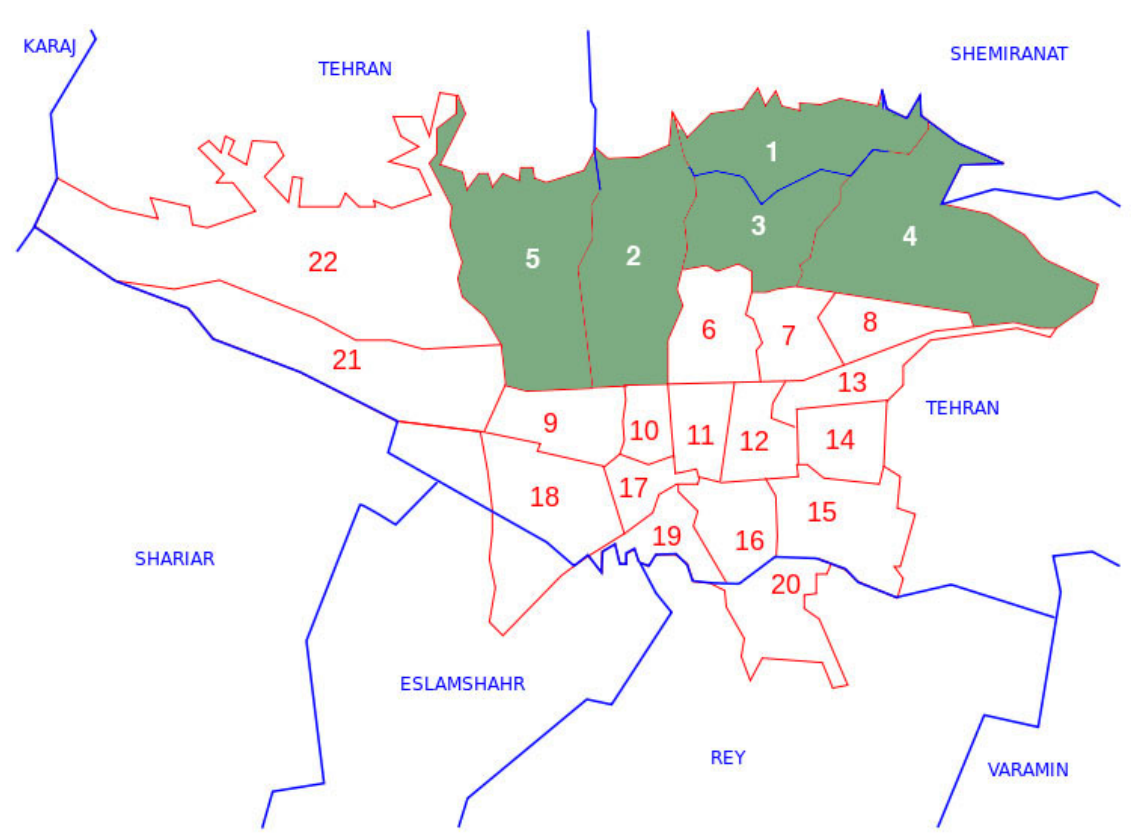

Figure 2. Number of permits granted (vertical axis) in the 22 districts of Tehran between 2010 and 2014. Based on the data of: (SCI, 2011, 2012, 2013, 2014, 2015) 


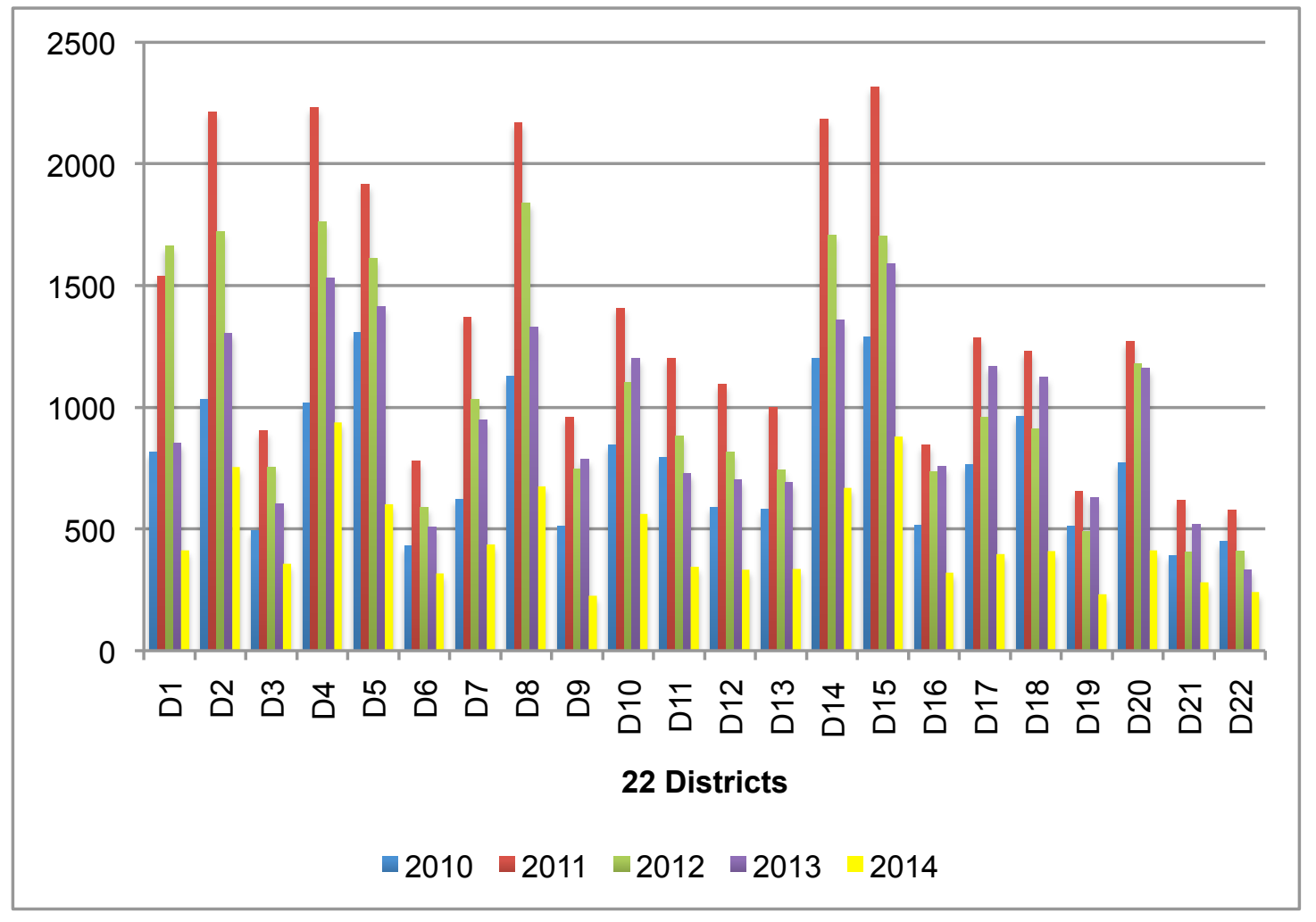

Figure 3. Comparison of the zone changes between the 22 districts of Tehran (vertical axis shows changed areas in hectare). Source: (Iran's Urban and Architecture Centre, 2016, p.28)

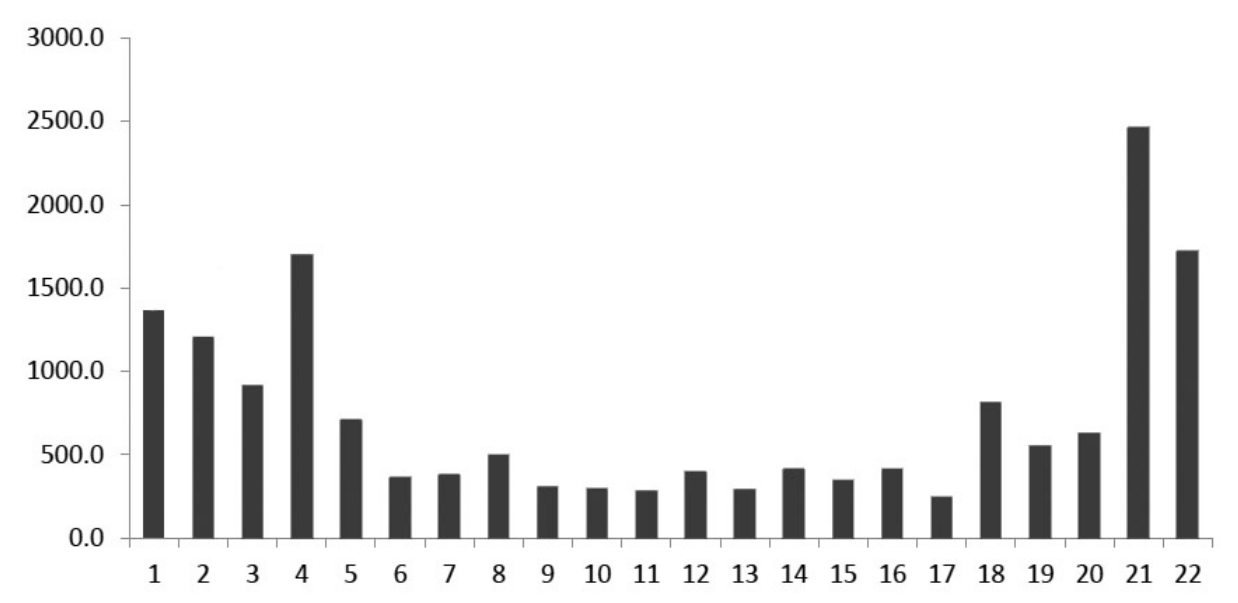

